\title{
Production of Methane from Maize Cob Fed Termites
}

\author{
${ }^{* 1}$ AKINMUSERE, OK; ${ }^{1}$ BABATOLA, JO; LAFE, OE; ${ }^{2}$ AJAYI, OE \\ ${ }^{1}$ Department of Civil Engineering, ${ }^{2}$ Department of Biology, Federal University of Technology, Akure, Nigeria. \\ *Corresponding Author Email: falohunoluwaseun1@yahoo.com; Other Authors Emails: jobabatola@futa.edu.ng, olulafe@gmail.com and \\ ajfumeu68@yahoo.com
}

\begin{abstract}
Termites are detritivores, which means that by consuming decomposing organic matter they obtain nutrients. By feeding on cellulose matter, termites generate methane. Waste energy content offers good opportunities to generate low-cost and available energy. This can help increase energy access and reduce energy poverty in Africa. This work helps to determine the rate of gas production by termites when fed with maize cob. A simulated environment was created for Macrotermes Subhyhalinus Sp. of termites made with optically transparent polycarbonate material (plexiglas). Methane emission from termites' simulated environment was monitored with the use of a gas flow meter. The termites' production rate was highest at dry temperature $28.07^{\circ} \mathrm{C}$ with $\mathrm{RH}$ of $88.30 \%$, and $0.630 \mu \mathrm{g} / \mathrm{termite} / \mathrm{day}$ flow rate was recorded form their simulated laboratory environment. The cellulose in maize shaft/cob is in the native state and the chemical composition not inhibited by processing; this led to the relatively high consumption and overall production rate of termites when they fed on it because maize cob was easier to digest.
\end{abstract}

\section{DOI: https://dx.doi.org/10.4314/jasem.v23i4.10}

Copyright: Copyright $\odot 2019$ Akinmusere et al. This is an open access article distributed under the Creative Commons Attribution License (CCL), which permits unrestricted use, distribution, and reproduction in any medium, provided the original work is properly cited.

Dates: Received: 04 March 2019; Revised: 19 April 2019; Accepted 22 April 2019

Keywords: Detritivores, Macrotermes Subhyalinus sp., simulated environment, Polycarbonate.

Waste energy content offers good opportunities to generate low-cost and available energy. This can help increase energy access and reduce energy poverty in Africa (Scarlat et al., 2015). Renewable energy remains one of the best alternatives for sustainable energy development. According to (Babatola, 2008), ignorance of renewable energy technology has meant that most people in developing countries rely primarily on solid fuel like wood to meet their cooking and lighting needs. Methane is produced in environments with little or no oxygen by bacteria that feast on organic matter such as grasses and wood (Kawaguchi et al., 2006). Nearly half of methane in the world comes from natural sources such as wetlands, rivers and streams, hydrates of ocean floor gas and permafrost. Amazingly, Termites are the second largest source of global natural methane emissions; they produce the gas as part of their normal metabolic product-digestive process (Cooney, 2011). Termites are social insects living in nests or colonies, mostly multi-generational, ranging from several thousand to several million at maturity, depending on the species, the availability of food resources and the soil environment (Kambhampati and Eggleton, 2000). They are detrivores, which means that by consuming decomposing organic matter they obtain nutrients. By feeding on cellulose matter, termites generate methane. Dead plant materials, litter, wood, animal dung, agricultural waste (sugarcane bagasse and maize cob) are termites foods (Sguizzatto de Araujo et al., 2010). Environmental conditions such as lights, humidity, and temperature, concentration of oxygen and concentration of carbon dioxide affect methane production (Gomati et al., 2011). Factors affecting the intestinal micro-organisms or termites living conditions would also affect termites' gas emissions. Termite diet as well as test population size are included in these factors (Tsunoda et al., 1993). The aim of this research is to determine the highest quantity of gas that could be generated from termites when fed with maize cob.

\section{MATERIALS AND METHODS}

Materials used for this research includes Polycarbonate sheet (Plexiglas), maize shaft and cob. Polycarbonate sheets were sourced from local vendors while the maize cob was gotten from the Research farm of the Federal University of technology. The environment was stimulated for termites' activities in the laboratory. The simulated environment is a tetrahedral pyramid with a cuboid base which was made of polycarbonate material (plexiglass). Due to the fact that termites workers are vulnerable to sunlight due to their transparent skin, dark material has been used to prevent direct light rays with termites (Lisa, 2014). 


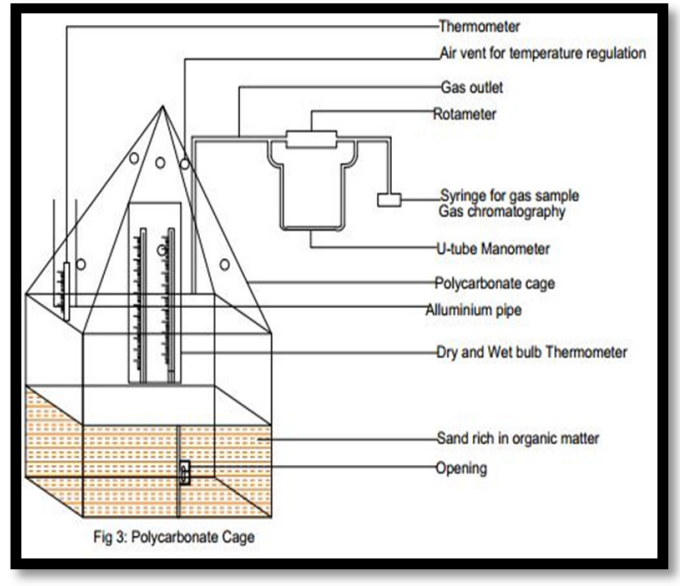

Fig 1: Set up of the simulated environment with the necessary instrument for proper monitoring.

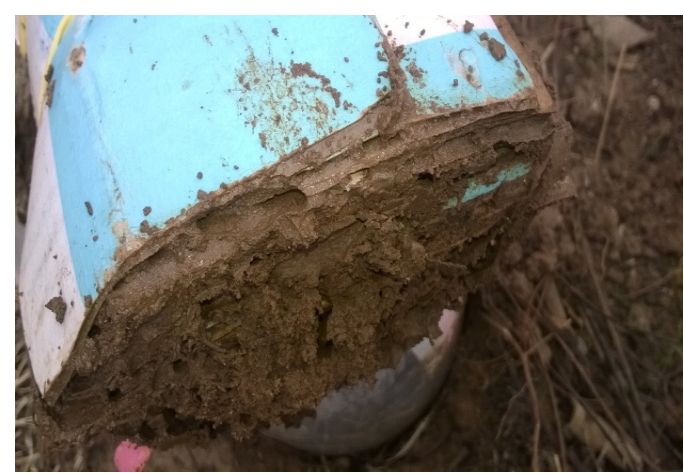

Plate 1: Termites' Bait

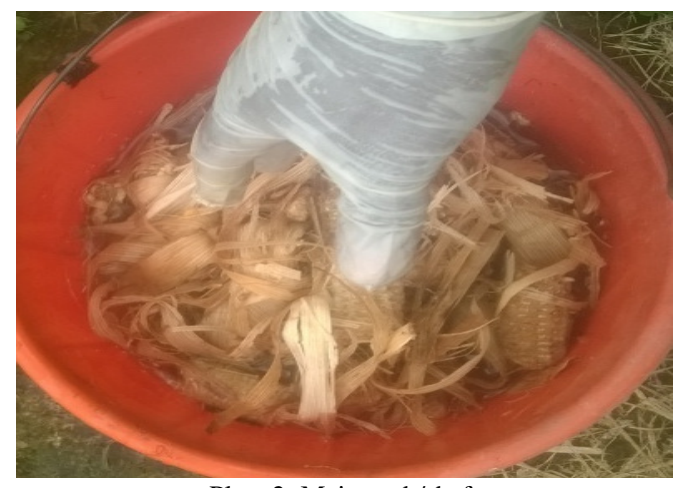

Plate 2: Maize cob/shaft
The design of the termites' laboratory setup is seen in Figure 1. Macrotermes Subhyalinus (Isoptera Termitadae) of termites were collected from the Federal University of Technology, Akure using bait technology. Termite workers fed upon the bait since they forage around for food, they saw the paper bait as food and later in 12 hours especially when there was no rainfall for the space of 2 days, the baits were collected and termites moved into the new laboratory colony designed for them. The termites were fed with the carbon source-maize cob at for a period of 30 days. Plate 1a shows the paper bait used for termite collection. The physical and chemical characterization of the feed stocks (Plate 1b) was determined using procedures for the Standard Test Method for Proximate Analysis of the Analysis Sample of Coal and Coke by Instrumental Procedures (2008).

\section{RESULTS AND DISCUSSION}

Table 1 shows the various characteristics of feedstocks and percentage of lignocelluloses. IBM SPSS Statistics 22 was used to analyze the triplicate results of the physical and chemical composition of the maize shaft/cob shown in Table 1. Cellulose is very difficult to digest. When many animals, like cows and goats, eat grass, they have to chew it for a very long time in order to digest it. Many termites digest cellulose by means of tiny one-celled animals in their digestive tract. These tiny animals, called protozoans, actually digest the cellulose. It took lesser time for the microorganisms in the termites' gut to breakdown the cellulose in maize cob because it is relatively low enhancing more gas production. Also, since maize cob is still in the natural state, hence its low density and biodegradability. It was observed that the mortality rate of termites in the polycarbonate cage was increased with high humidity of $97 \%$ and the life span of termites in the polycarbonate cage was 28 days. The termites' production rate was highest at dry temperature $28.07{ }^{\circ} \mathrm{C}$ with $\mathrm{RH}$ of $88.30 \%$, and $0.630 \mu \mathrm{g} /$ termite/day flow rate was recorded form their simulated laboratory environment

Table 1: Characteristics of Feed Stocks and Percentage of lignocelluloses

\begin{tabular}{|c|c|c|c|c|}
\hline Feed Stock & Moisture Content (\%) & Ash Content (\%) & Volatile Matter (\%) & Fixed Carbon (\%) \\
\hline $\mathrm{MC}$ & 6.30 & 7.67 & 62.70 & 23.33 \\
\hline Feed Stock & Cellulose $(\%)$ & $\mathrm{He}$ & icellulose (\%) & Lignin (\%) \\
\hline $\mathrm{MC}$ & 33.61 & 12. & & 11.88 \\
\hline
\end{tabular}

Relationship between the cumulative volume of gas produced and the time: From Tables 2, the association between the cumulative volume of gas and the time spent by the termites in the cage for the three feed stocks was statistically significant at $99 \%$ confidence level. The result showed a very strong and positive association. This was because as much time they spent, more quantity of feedstock was consumed which led to more gas production from the polycarbonate cage till the end of 28 days when the mortality rate was at the peak and termites activities was no longer visible. 
Table 2: Average Temperature and Relative Humidity and Flow rate Measurement within the termites' Laboratory Habitat. (Feed Type:

\begin{tabular}{|c|c|c|c|c|c|c|}
\hline \multicolumn{7}{|c|}{ Maize shaft/cob) } \\
\hline $\begin{array}{l}\text { Time } \\
\text { (Day) }\end{array}$ & $\begin{array}{l}\text { Temp. } \\
\left({ }^{\circ} \mathrm{C}\right)\end{array}$ & $\begin{array}{l}\text { Rel. } \\
\text { Humidity } \\
(\%)\end{array}$ & $\begin{array}{l}\text { Gas } \\
\text { Pressure } \\
\text { (atm) }\end{array}$ & $\begin{array}{l}\text { W of } \\
\text { Feed } \\
(\mathrm{kg})\end{array}$ & $\begin{array}{l}\text { Gas Flow Rate - } \\
\text { V ( } \mu \text { g/ } \\
\text { termite/day }\end{array}$ & $\begin{array}{l}\text { Cummulative Gas } \\
\text { Flow Rate. ( }(\mu \mathrm{g} / \\
\text { termite) }\end{array}$ \\
\hline 1 & 30.03 & 94.85 & 1.013 & 1.50 & 0 & 0 \\
\hline 2 & 30.09 & 97.70 & 1.105 & 1.50 & 0 & 0 \\
\hline 3 & 29.63 & 97.85 & 1.113 & 1.50 & 0.440 & 0.440 \\
\hline 4 & 30.33 & 99.00 & 1.113 & 1.50 & 0.383 & 0.823 \\
\hline 5 & 29.60 & 96.15 & 1.122 & 1.50 & 0.410 & 1.233 \\
\hline 6 & 29.30 & 99.00 & 1.122 & 1.50 & 0.385 & 1.618 \\
\hline 7 & 30.70 & 95.35 & 1.205 & 1.50 & 0.399 & 2.017 \\
\hline 8 & 29.53 & 95.70 & 1.263 & 1.50 & 0.402 & 2.419 \\
\hline 9 & 28.07 & 88.30 & 1.390 & 2.00 & 0.630 & 3.049 \\
\hline 10 & 29.30 & 98.15 & 1.180 & 2.00 & 0.397 & 3.446 \\
\hline 11 & 29.47 & 97.00 & 1.263 & 1.50 & 0.415 & 3.861 \\
\hline 12 & 30.37 & 96.00 & 1.263 & 1.50 & 0.445 & 4.306 \\
\hline 13 & 30.53 & 97.85 & 1.330 & 1.50 & 0.433 & 4.739 \\
\hline 14 & 29.26 & 97.70 & 1.380 & 1.50 & 0.419 & 5.158 \\
\hline 15 & 29.27 & 98.15 & 1.180 & 1.50 & 0.394 & 5.552 \\
\hline 16 & 29.17 & 98.15 & 1.180 & 1.50 & 0.392 & 5.944 \\
\hline 17 & 29.70 & 98.15 & 1.180 & 1.50 & 0.389 & 6.333 \\
\hline 18 & 29.73 & 83.70 & 1.360 & 2.00 & 0.610 & 6.943 \\
\hline 19 & 27.93 & 98.95 & 1.180 & 1.50 & 0.388 & 7.331 \\
\hline 20 & 29.30 & 97.65 & 1.180 & 1.50 & 0.429 & 7.760 \\
\hline 21 & 29.33 & 97.20 & 1.180 & 1.50 & 0.425 & 8.185 \\
\hline 22 & 29.57 & 97.30 & 1.180 & 1.50 & 0.407 & 8.592 \\
\hline 23 & 29.33 & 96.50 & 1.180 & 1.50 & 0.458 & 9.050 \\
\hline 24 & 29.40 & 94.50 & 1.180 & 1.50 & 0.459 & 9.509 \\
\hline 25 & 29.10 & 96.65 & 1.180 & 1.50 & 0.449 & 9.958 \\
\hline 26 & 29.27 & 97.65 & 1.180 & 1.50 & 0.412 & 10.370 \\
\hline 27 & 29.20 & 96.85 & 1.180 & 1.50 & 0.456 & 10.826 \\
\hline 28 & 26.97 & 97.15 & 1.180 & 1.50 & 0.413 & 11.239 \\
\hline 29 & 29.37 & 97.30 & 1.103 & 1.50 & 0 & 11.239 \\
\hline 30 & 29.13 & 98.00 & 1.103 & 1.00 & 0 & 11.239 \\
\hline
\end{tabular}

Table 3: Correlation matrix of parameters determined for Macrotermes Subhyalinus sp. feeding on maize shaft/ cob

\begin{tabular}{|c|c|c|c|c|c|c|c|}
\hline & $\begin{array}{l}\text { Cummulativ } \\
\text { e Gas } \\
\text { Volume }(\mu \mathrm{g} / \\
\text { Termite) }\end{array}$ & $\begin{array}{l}\text { Time } \\
\text { (Day) }\end{array}$ & $\begin{array}{l}\text { Temp } \\
\left({ }^{\circ} \mathrm{C}\right)\end{array}$ & $\begin{array}{l}\text { Rel. } \\
\text { Humidity } \\
(\%)\end{array}$ & $\begin{array}{l}\text { Gas } \\
\text { Pressure } \\
\text { (atm) }\end{array}$ & $\begin{array}{l}\text { W of } \\
\text { Feed } \\
(\mathrm{kg})\end{array}$ & $\begin{array}{l}\text { Gas Flow } \\
\text { Rate }-V(\mu \mathrm{g} / \\
\text { termite/day) }\end{array}$ \\
\hline $\begin{array}{l}\text { Cummulative Gas } \\
\text { Volume( } \mu \mathrm{g} / \text { termite) }\end{array}$ & 1 & & & & & & \\
\hline Time(Day) & $.979^{* *}$ & 1 & & & & & \\
\hline $\operatorname{Temp}\left({ }^{\circ} \mathrm{C}\right)$ & $-.467^{* *}$ & $-.446^{*}$ & 1 & & & & \\
\hline Rel. Humidity(\%) & .028 & .031 & .028 & 1 & & & \\
\hline Gas Pressure(atm) & .049 & .011 & -.088 & $-.516^{* *}$ & 1 & & \\
\hline W of Feed (kg) & -.237 & -.241 & -.105 & $-.629^{* *}$ & $.483^{* *}$ & 1 & \\
\hline $\begin{array}{l}\text { Gas Flow Rate }-\mathrm{V}(\mu \mathrm{g} / \\
\text { termite/day })\end{array}$ & .044 & .015 & -.179 & $-.373^{*}$ & $.666^{* *}$ & $.525^{* *}$ & 1 \\
\hline
\end{tabular}

** Correlation is significant at 0.01 level and * correlation significant at 0.05 level

Conclusions: The study reveals the following: (i) Termites are naturally endowed to emit methane $\left(\mathrm{CH}_{4}\right)$ when they feed as methane is the end product of the digestive process that takes place in the gut of termites. (ii) Macrotermes subhyalinus sp. was identified, housed for 28 days in the laboratory and fed with the feed stock-maize shaft/ cob and (iii) The highest rate of methane production was successfully evaluated to be $0.630(\mu \mathrm{g} /$ termite/day $)$.

\section{REFERENCES}

Babatola, JO. (2008). Comparative Study of Biogas Yield Pattern in some animal and household waste. African Research Review, 2(4):54-68

Cooney, CM. (2011). Science Advancing on Methane's Behavior in Carbon Cycle. Insideclimate News.

Gomati, V; Ramasamy, K; Kumar, K; Sivaramaiah, N; and Ramanjaneya, VRM. (2011): "Greenhouse gas emissions from termite ecosystem". African 
Journal of Environmental Science and Technology; 5(2):56-64.

Kambhampati, S; Eggleton, P. (2000). Taxonomy and phylogeny of termites. In Abe, T., Bignell, DE; Higashi, M. (ed.), Termites: Evolution, Sociality, Symbioses, Ecology. Kluwer Academic Publishers, Dordrecht, The Netherlands. 1-23.

Kawaguchi, S; Yoshimura, T; Aoyagi, H; Hayashi, A; Ima-mura, Y; Miura, M; Yanase, Y; Fujii, Y; Okumura, S; Suzuki, K. (2006). Energy gas production from wood biomass by termites. Proceedings of XV International Conference, Union for the study of Social Insect (IUSSI), Washington, DC, 205-206.

Lisa, M. (2014). Collective Mind in the Mound: How Do Termites Build Their Huge Structures? National Geographic.

Maske, V; Dhulap, V. (2018). Development of Handy Prototype Gas Sensors Kit for Monitoring of Ambient Green house gases from Solid waste Disposal sites of Solapur city". AIP Conference Proceedings (pp. 20-24). Solapur City: AIP Publisher.
Scarlat, N; Motola, V; Dallemand, JF; MonfortiFerrario, F; Mofor, L; (2015). Evaluation of energy potential of Municipal Solid Waste from African urban areas. Renewable and Sustainable Energy Reviews, 50:1269-1286.

Sguizzatto de Araujo, F; Araujo, AP; Wilson, M; Neto, JAA; DeSouza, O. (2010). Bottom-Up Effects on Selection of Trees by Termites (Insecta: Isoptera). Journal of Sociobiology, 55(3): 725-733.

Tsunoda, K; Ohmura, W; Yoshimura, T; Tokoro, M.. (1993). Methane emission by the termite, Coptotermes formosanus Shiraki (Isoptera: Rhinotermitidae) I. Effect of termite caste, population size and volume of test containers. Wood Research, 79:34-40 